\title{
RESEARCHPAPER
}

\section{Micropropagation of Bambusa vulgaris var. striata}

\author{
KIRTI SINGH \\ Department of Molecular and Cellular Engineering, Jacob School of Biotechnology and Bio-Engineering, Sam \\ Higginbottom Institute of Agriculture, Technology and Sciences, ALLAHABAD (U.P.) INDIA
}

Article Info :Received : 24.12.2015;Accepted : 11.02 .2016

Bambusa vulgaris var. striata is a widely cultivated bamboo species in rural Madhya Pradesh for its versatile uses. The vegetative propagation becomes the only viable alternative for this species because B. vulgaris does not set seed after sparse flowering, which makes seedling progenies unavailable. A low-cost propagation trial was conducted to explore the clonal propagation techniques for the species with two types of small branch cuttings, nodal leafy cuttings and tip cuttings. The cuttings, after treating with 1, 2 per cent and 0.1 per cent, solutions of, bavastin and $\mathrm{Hgcl}_{2}$ were kept in non-mist propagator to let them to root for assessing the rooting ability. The cuttings were rooted in three weeks and were allowed to grow in the polybags for 6 months under nursery condition. The study reveals that both types of branch cuttings are able to develop roots, shoots, to survive and to form rhizome under the nursery condition. Rooting ability of the cuttings was significantly enhanced by the application of rooting hormone - IAA. The length of the longest root varied significantly neither with the cutting types nor the concentrations of IAA solution.

Key words : Bambusa vulgaris, Leafy branch, Cuttings non-mist propagator, Rooting ability

How to cite this paper : Singh, Kirti (2016). Micropropagation of Bambusa vulgaris var striata. Asian J. Bio. Sci., 11 (1) : $127-130$ [Special Issue of AFBSAH-2016]. 